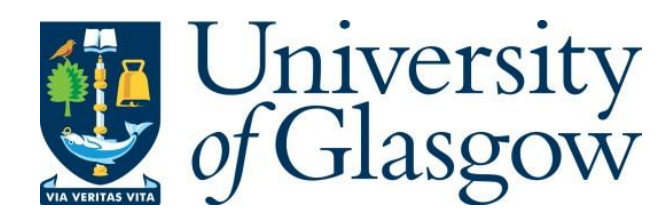

Jønsson, J. B. and Bryceson, D. F. (2017) Beyond the artisanal mining site: migration, housing capital accumulation and indirect urbanization in East Africa. Journal of Eastern African Studies, 11(1), pp. 3-23.

There may be differences between this version and the published version. You are advised to consult the publisher's version if you wish to cite from it.

http://eprints.gla.ac.uk/137858/

Deposited on: 15 May 2017

Enlighten - Research publications by members of the University of Glasgow http://eprints.gla.ac.uk 


\title{
Beyond the artisanal mining site: migration, housing capital accumulation and indirect urbanization in East Africa
}

Jesper Bosse Jønsson $^{* a}$ and Deborah Fahy Bryceson ${ }^{\dagger b}$

${ }^{a}$ COWI Tanzania \& School of Geographical and Earth Sciences, University of Glasgow, Post Box

1007, Dar es Salaam, Tanzania; ${ }^{b}$ Centre of African Studies, University of Edinburgh

[Submitted: 24 February 2016; Accepted: 19 January 2017]

\begin{abstract}
During the past 30 years, Tanzania has experienced successive precious mineral rushes led by artisanal miners. Their settlement, livelihood and housing strategies have evolved amidst high mobility in pursuit of mineral wealth. Cumulatively, the spatial movement of artisanal miners and an associated following of economically motivated migrant service providers have catalysed large-scale "direct urbanization" at artisanal mine sites-cum-small towns. These settlements have been generally characterized by relatively makeshift accommodation, which may mask accumulated savings of in situ earnings for housing investment elsewhere. In this article, in addition to documenting the mine-led direct urbanization process, we draw attention to a subsequent "indirect urbanization" phenomenon, whereby many successful artisanal miners and other entrepreneurial mining settlement residents make strategic house building investments in larger towns and cities. In anticipation of declining mineral yields and retirement from days of 'roughing it' in mining sites, they endeavour to channel savings into housing in more urbanized locations, aiming to diversify into profitable business activities, living a life with better physical and social amenities. Their second-wave onward migration from mine sites encompasses more diverse destinations, particularly regional towns and cities, which accommodate their work and family life cycle needs and lifestyle preferences. Such mine-led direct and indirect urbanization processes arise from sequential migration decision-making of participants in Tanzania's artisanal mining sector. In this article, we interrogate mining settlement residents' locational choices on the basis of fieldwork survey findings from four artisanal gold and diamond mining settlements in Tanzania's mineral-rich regions of Geita, Mwanza and Shinyanga, and from in-depth interviews with miners-cum-entrepreneurs residing in Mwanza, Tanzania's second largest city, situated in the heart of Tanzania's gold fields.
\end{abstract}

Key words: Tanzania, artisanal mining, migration, housing, urbanization, investment, multi-locational

In recent decades, growing unemployment among youth, pressure on households to diversify their income portfolios and liberal mining codes have catalysed people to migrate to artisanal mining settlements throughout Tanzania. ${ }^{1}$ Using limited capital investment, basic tools, manual devices and/or simple and predominantly portable machinery, they engage in extraction, processing and trading of minerals mined labour-intensively.

Many Tanzanians, aiming to improve their livelihood and climb up the social ladder, have travelled considerable distances to engage in artisanal mining. ${ }^{2}$ Nowhere has the rise of artisanal mining settlements been more significant than in the Lake Victoria Gold Fields south of Lake Victoria,

\footnotetext{
*Corresponding author: jebo@cowi.com

+ Email: dfbryceson@bryceson.net
} 
namely Mara, Mwanza, Shinyanga, Geita, Simiyu and Kagera regions. Despite the regions' semi-arid landscape and limited agricultural potential, a high influx of people has been drawn thereto by the expectation of lucrative mineral extraction. Furthermore, mineral production generates local and regional multiplier effects, providing income-earning opportunities for men and women in a variety of service-provisioning occupations.

Academic literature on mining in Tanzania has been thematically dominated by the impact of mining expansion on the national economy ${ }^{3}$, conflicts between artisanal and large-scale miners over land and mineral entitlements ${ }^{4}$, and by social, political and environmental implications of artisanal mining. ${ }^{5}$ Until recently, there has been little mention of the nature of settlement change at regional and national levels. This requires documentation, not only of what is happening in situ, but also of capital investment flows emanating from mining sites into housing and business elsewhere.

There is a growing body of case study literature ${ }^{6}$ documenting the significance of artisanal mining for the livelihoods of millions of people in mineral-rich parts of Sub-Saharan Africa. Many of the misconceptions commonly associated with artisanal mining - notably, that the sector by definition is chaotic and criminalized - are being challenged. So too, the physical appearance of housing in artisanal mining settlements is often wrongly interpreted by visitors as being a direct sign of residents' poverty. The influence of residents' high mobility and diverse, often geographically dispersed income portfolios of many households located within these settlements is typically under-appreciated, in oversight of the possibility of deliberate temporary settlement at mining sites. Miners, especially at rush locations, are likely to choose to live in deprived conditions, which often masks some miners' high-income status.

Africa's "mineralization"7 is defined as alteration in the form and content of the continent's economic and social foundations arising from the growing importance of mining at local, regional and national levels. The phenomenon is epitomized by the mushrooming of small town mining settlements of more than 10,000 residents south of Lake Victoria during the intercensal period between 1978 and 2002. ${ }^{8}$ This growth exemplified "direct urbanization" arising from the expansion of artisanal mine sites and new industrial gold mines. Yet, even though the synergy between mining and urbanization has been mounting over the past three decades, it was only in 2008 that the relationship between mining and urban growth and its developmental challenge was acknowledged in an official government review of Tanzanian mining. ${ }^{9}$

Examining housing and urbanization solely in and around mining sites does not afford an overall picture of artisanal mining's influence on urban growth. A multi-locational research approach is required to gain an overview of the housing priorities of artisanal miners and other mine site residents. 
This includes their residence at mining sites (both temporary and permanent settlement), planned retirement, and housing investment patterns. Our concept of "direct urbanization" refers to the birth of small towns through migration to green field sites or existing villages, and the exceptionally rapid population growth at mineral rush sites. By contrast, "indirect urbanization" arises at a subsequent stage of artisanal mine settlement, defined as outward migration from mining settlements to preexisting non-mining urban locations, catalysed by the migrants' income diversification and housing investment strategies.

To grasp mine wealth creation and indirect artisanal mining urban growth dynamics, it is vital to consider artisanal miners' high mobility, alongside their deliberated housing strategies, which tend to be temporally aligned with life cycle and work career considerations. Initially, their migration destinations are concentrated on mineral-bearing, wealth-creating localities but this may alter over time. Adopting an analytical construct, which pivots on the dynamics between agency and process, this article traces unfolding processes of direct and indirect urbanization through the prism of miners' and other residents' migration and house investment decision-making, based on 2011-2012 survey and interview data. Our immediate aims are to draw attention to the decision-making agency giving birth to small town mining settlements in the process of direct urbanization and to demonstrate the linkage between mining careers, migration and housing investment of successful artisanal miners, at the micro level, with the process of indirect urbanization, at the macro level.

The first sections of this article introduce the parallel growth trajectories of mining and urbanization and the concept of indirect urbanization resulting from the agency of miners and mining settlement residents' multi-locational strategies. Thereafter, our fieldwork design and study sites are outlined, before presenting our fieldwork findings from a household survey in four artisanal mining settlements revealing: first, the mobility and motives of newly arrived people living in artisanal mine settlements; and second, attachment to the mining sites as they mature, changing livelihood and housing strategies, and locational settlement preferences. We then proceed to findings from interviews we conducted with retiring artisanal miners resident in Mwanza city, which cover their work profiles, migration strategies and housing investments in Mwanza city, before concluding our analysis.

\section{Setting the scene: Parallel growth trajectories of mining and urbanization}

The discovery and subsequent extraction of minerals can transform landscapes within short periods. From the sudden, unplanned take-off of makeshift artisanal settlements associated with mineral rushes to booming large-scale, partially planned corporate mining towns. Both types of settlements exist in 
Tanzania. The country is endowed with abundant mineral wealth ranging from gold, diamonds, and gemstones to several industrial minerals including nickel, uranium, graphite, iron, and coal.

Under British rule, gold mining surged, peaking in the late 1930s when the world market price for gold was record high. ${ }^{10}$ Subsequently, World War II and stagnating gold prices resulted in a fast declining gold mining sector. The relationship between mining and urbanization was not pronounced during British colonialism. Only low levels of urbanization were recorded from 1920 to independence in 1961. Thus, at independence only seven\% of the population lived in urban areas, primarily in Dar es Salaam. After independence, Dar es Salaam experienced rapid urban growth triggered mainly by the Africanization of the labour market. The 1970-1980s were characterized by the rise of Tanzania's regional capitals.

During the late 1970s, Tanzania experienced a deepening agricultural malaise. This was most apparent in smallholder commercial crop production, leading to deterioration in the productive and exporting capacity of the country. ${ }^{11}$ Artisanal mining emerged as a viable alternative to agriculture and gained momentum. As mineral discoveries multiplied, artisanal mining rushes of gold, diamonds, and gemstones became increasingly obvious as places of population influx.

New mining legislation in the late 1990s provided artisanal miners with opportunities for formalizing their activities. It also created an enabling investment environment for foreign exploration and mining companies, which invested heavily in the country. ${ }^{12}$ Today the two segments exist side by side, but conflicts between the two mining types are common. Tanzania's artisanal mining sector is smaller in terms of the value of its output, but far larger in labour absorption. A Ministry of Energy and Minerals/World Bank census (2011) estimates that there were 685,000 artisanal (i.e. artisanal and small-scale) miners in Tanzania (in a population of 49 million), most involved in gold extraction. ${ }^{13}$ The Tanzania 2010 Mining Act included some support for artisanal mining interests by designating more areas exclusively for artisanal miners. ${ }^{14}$

In the 1990-2000s, the rise of small towns in mining regions became apparent. This was evident with small towns close to artisanal mining sites, e.g. Katoro-Buseresere ${ }^{15}$, Kakola, and Makongorosi in the case of gold and Merelani in the case of tanzanite, but even more with towns located near large-scale mining operations, notably Geita and Kahama. Both were sites of explosive growth rates following commencement of large gold mine operations. As a parallel development, Tanzania's main urban commercial centres, Dar es Salaam, Arusha, and Mwanza, experienced deepening sophistication of their economies and a remarkable spurt in high-rise building construction over the last decade. 
Yet, there is scant public awareness or acknowledgement in existing mining literature of the impact of artisanal mining on the expansion of urban settlement change. The interaction of mining and urban settlement growth and contraction rests on in situ change within the mining settlements and investment flows in housing and business from mining sites to other urban locations. These investment flows are a consequence of artisanal miners' decision-making regarding the proceeds of mineral earnings outlined below.

Tanzanian artisanal miners engaged in pit mining are overwhelmingly men. They make numerous sequential choices over the course of their careers, which influence housing location and settlement growth, notably: 1) whether to continue or quit mining, considering current and potential earnings weighted against the occupational risks and uncertainty of mining and employment opportunities outside the sector; 2) whether to stay at the current site or move elsewhere, in view of their position and earnings at the current site seen against other sites; and 3) whether to build a house or look for other accommodation options, taking into account the limited comfort of sleeping in a makeshift shack, its lack of privacy when sharing with others and the expense of renting as opposed to the expense and risk of building a house in a location that harbours possible eviction and inevitable mineral depletion.

By the end of their mining careers, most artisanal miners will typically have resided at a number of mine sites in a variety of circumstances ranging from sleeping under the open sky, to living in makeshift tents, shacks, mud huts and possibly in solid brick or cement buildings. ${ }^{16}$ As mining unfolds, miners regularly re-evaluate what kind of accommodation makes the most sense. Their decisions are generally based on estimated current and prospective future earnings taking account of the size of the existing mineral deposit, its legal or illegal mineral tenure and employment opportunities elsewhere.

Even with adequate financial means, miners' choice of where to mine and where to build a house is never straightforward. A number of options with pros and cons exist, that are contingent on the miners' original starting point, their current mine site, previous mine sites, and distance to the closest town or city. Furthermore, traders and people working in the service sector, following the lead of the miners, seek to capitalize on the miners' purchasing power.

Using housing as a wealth indicator is a common survey practice in Africa ${ }^{17}$, but in the context of mining settlements, housing appearances can be deceiving. Miners' accommodation may be uncomfortable and makeshift at the mining site but can be augmented by adequate or well-to-do housing at other locations. Werthmann, writing about mining camps in Burkina Faso, reasons that miners have limited time horizons at any one place. The mine site location "only matters as long as it 
provides certain resources (the metal or mineral, other profitable activities, or alternative lifestyles). Once these resources are depleted or no longer satisfactory, the sojourners of a mining camp relocate to another place where they reproduce similar structures of cohabitation and cooperation." ${ }^{18}$ While some mine sites in Tanzania accord with Werthmann's depiction of peripatetic movement on the part of miners, others have settlement trajectories that are shaped by miners' increasing diversification of income sources and non-mining livelihood consolidation, some passing a threshold where the settlement is no longer a mining site per se. ${ }^{19}$ The temporality and uncertain trajectories of mine settlements needs to be recognized when addressing the entwined livelihood and housing strategies of people resident in mining settlements.

\section{The concept of urbanization and multi-locational housing strategies}

Most literature on mining settlements focuses on the direct links between mining and urbanization within and near mining sites, overlooking the phenomenon of multi-locational housing investment and indirect urbanization. The term, "indirect urbanization" has barely surfaced in urban studies literature. Ouředníček (2008), with a background in social geography and regional development, deploys the term with reference to the spread of urban lifestyles in rural environments, which he argues hastens the transformation of rural settings of low population density into urban settlements. ${ }^{20}$ Indeed, this cultural phenomenon can be observed in many locations where minerals are discovered within or near rural villages. Seto et al. (2012), from a disciplinary perspective grounded in geography, environmental studies and forestry, focuses on how urban expansion influences carbon emissions, perceiving "indirect urbanization" as the inadvertent alteration of land-use in distal, marginal places where carbon stock changes occur in areas not anticipated to become urban, catalysing the expansion of urban areas at the expense of rural hinterlands. ${ }^{21}$ Finally, Jarmila's (2006) land-use and regional development gaze, associates "indirect urbanization" with people residing in the countryside, but commuting to work in urban areas, noting how people were moving from primary and secondary sectors towards the tertiary sector in the Slovak Republic. ${ }^{22}$

All three authors use the term "indirect urbanization" to refer to what is in effect urbanization by stealth, in which residents in rural areas are urbanized by the influence of incoming flows of urban people, goods and cultural stimuluses considered incongruous either socially or environmentally and as imparting urban characteristics in a rural landscape, rather than demographic growth per se. This perspective departs from the classic source-destination pattern of "direct urbanization" arising from flows of people migrating from less densely populated settlements into urban areas and connotes people's passive experience of urbanization. By contrast, we stress the agency exercised in both direct 
and indirect urbanization, involving people's en masse spatially targeted migration in the case of direct urbanization, contrasted with individual household's more ad hoc selection of diverse larger urban areas during the process of indirect urbanization. Both emanate from agency associated with artisanal mining and represent conscious decision-making; initially about the location of mining, followed by interim deliberation about the location of housing investment derived from artisanal mining earnings and finally, the urban destination of onward migration away from the mining site.

Given our focus on mine-induced urbanization, our starting point is the mining settlement, which is usually rural at the outset, but very rapidly proceeds to be transformed by the influx of migrants from a wide geographical catchment. The migrants tend to be ethnically, occupationally and politically diverse, creating an increasingly cosmopolitan population. This is a classic case of "direct urbanization" with a full range of transformational processes at work. By contrast, "indirect urbanization" represents investment by artisanal miners and other residents of mining settlements in housing, businesses and human capital in urban locations distinct from where they mine, which provides the conduit for eventual onward migration from mining settlements to residence in more populous urban areas.

The investors' ultimate aim is to lay the foundation for leaving the mining settlement for various reasons: awareness of mineral supplies diminishing over time; dissatisfaction with the mining settlement's social ambience or economic prospects; desire to send their children to better schools in the city; or retirement from mining due to physical exertion. Not least, amassing savings in the mining settlement are likely to be channelled towards building a permanent house in a location that is considered a haven away from work pressures and the perceived corrupting influences of the mine settlement.

The analysis of "indirect urbanization" involves understanding individuals, households, and livelihood strategies from a multi-locational perspective. "Multi-locationality", as it is used in livelihood analysis, refers to people or entities based in two or more locations in rural or urban areas. ${ }^{23}$ It is viewed as desirable for purposes of capitalising on different resource bases, different subsistence and income sources, and a range of social support services and physical infrastructure. Multi-locational households can rely on social networks created and maintained in different locations. Furthermore, as a risk-aversion measure, it is economically practical to generate income from different activities at different locations. ${ }^{24}$ This tactic does not mean that households seeking spatially diverse opportunities are necessarily better off economically compared to households reliant solely on in situ resources, but the diversification of their livelihood portfolios, helps to spread risk, increase resilience and potentially boost income. ${ }^{25}$ For our purposes, multi-locational household and livelihood strategies need to be seen 
in light of the peculiar character of artisanal mining. The underlying temporality and spatial limitations of minerals, which intersect with the unpredictability of artisanal miners' earnings and vulnerabilities of life cycle progression, spur multi-locational strategies and guide locational preferences for housing investment.

\section{Fieldwork survey design and study sites selection}

The fieldwork and findings reported in this article derive from the Urbanization and Poverty in Mining Africa (UPIMA) research project funded by DfID and ESRC. The project's aim was to delineate urbanization patterns in Tanzania through a comparison of newly established artisanal mine rush settlements with long established artisanal mining settlements at diamond and gold sites. The four selected sites are presented in Table 1 and Figure 1 together with the city of Mwanza as a case for illustrating the life trajectories pursued by some successful artisanal miners.

Qualitative and quantitative data-gathering methods were used to analyse a cross-section of households, residential communities, and differing mining contexts. Specifically, the study consisted of a randomly sampled household survey targeting 36 households at each site headed by a mix of mining and non-mining heads of households, semi-structured qualitative interviews with 60 key informants including government officials and leaders at the sites and related district and regional headquarters, and four focus group discussions with secondary school students. Our mining settlement fieldwork took place between May 2011 and December 2012, followed by selective interviews in Mwanza city with nine successful retired miners about their life trajectories, migration and housing investment, with the purpose of exploring the decision-making involved in indirect urbanization.

\section{INSERT Figure 1}

Table 1: Study sites

Gold rush settlement - Ikuzi (small town, Bukombe District, Geita Region)

An agro-pastoralist village where gold was discovered in July 2010. Within weeks, the village grew from 3,600 to a fluctuating population estimated at 9,000-13,000 people, with the additional populace mining for gold in an area without sanitary facilities or residential services. 
Diamond rush settlement - Mwanangwa (village, Misungwi District, Mwanza Region)

Settlement dated back to the pre-colonial days, when it was a regional trade centre. From the late 1920s sporadic diamond prospecting took place, but artisanal mining did not surge until 1979 when diamonds were discovered near the village, only to decline ten years later. In April 2009, gravel digging for nearby roadworks uncovered diamonds and a new rush began, attracting thousands of people within days. At the time of the study, mining activities had peaked, but approximately 1,000 miners remained on the site engaged in artisanal mining. Together with the local villagers, they constituted a population of approximately 2,500 people.

Gold mature mining settlement - Nyarugusu (small town, Geita District, Geita Region)

Mining activities stretch back to the colonial period, when an industrial gold mine operated close to the village. When the mine closed in the $1960 \mathrm{~s}$, some of the dismissed workers switched to artisanal mining. Joined by others, the population grew. In the 1980s, mining activities escalated following multiple gold discoveries. To accommodate the population increase, Nyarugusu was divided into two villages in 2000. In 2009, the new Nyarugusu 'village', with a population of around 27,000 people, was again divided into three new settlements with the new designated settlement of Nyarugusu having a population of around 11,000.

Diamond mature settlement - Maganzo (small town, Kishapu District, Shinyanga Region)

A long-established artisanal mining settlement situated next to the Mwadui Williamson Diamond mine. Maganzo's first inhabitants came from the ranks of people who looked for employment in or retired from the Mwadui mine, or people who found a livelihood in stealing diamond-rich gravel from within Williamson's concession, an activity known as 'ubeshi'. While the latter group is still present in Maganzo, there is also artisanal mining of diamonds at various locations around the settlement. Maganzo, located on the main trunk road connecting Dar es Salaam and Mwanza is a small town, with an estimated population of 11,900.

Commercial hub of the Lake Victoria Gold Fields - Mwanza City (large city, Nyamagana Municipal, Mwanza Region)

Tanzania's second largest city with a population of 700,000 (2012 census), situated on the shores of Lake Victoria. Serving as northwest Tanzania's infrastructural and service hub and the centre of commercial trade in fisheries, cotton, and - above all - minerals, the city has experienced vigorous demographic and economic growth over the past three decades.

\section{Evolving settlement and housing strategies at the mining site}


In this section, we propose an analytical stylization of the evolution of migration and house investment decision-making that generates direct and indirect urbanization. Clear delineation of Stages 1 and 2 and their impact on direct and indirect urbanization processes should not be assumed as an immutable trajectory found everywhere. What is being outlined here is a noticeable trend amongst the more affluent population in mining settlements, and a desired but not necessarily achievable trajectory for most households. Artisanal miners migrate in search of profitable mineral sites. Prioritizing profit over comfort, they initially make do with rough and ready temporary accommodation and refrain from building a house until a sufficient elapse of time suggests that the settlement has enduring mining prospects.

At the outset of mineral rush mining, during Stage 1 migration, both miners and service providers seek rewarding mineral-rich sites. The mass influx of population at promising sites gives birth to new small towns. Artisanal miners are likely to live a peripatetic life, moving between highyielding mineral sites, contributing further to new small town growth. However, settlement preferences and housing of mining settlement households alter over time depending on the mining prospects at their residential location, progression of their work careers, life cycles and, above all, whether they have managed to accumulate savings. Some households' meagre economic earnings give them no choice, and they struggle to survive in the mining settlement without the wherewithal to migrate further or achieve adequate housing; whereas other experienced miners, who usually have worked at several mining sites, manage to save and thereby begin transcending to a second stage of locational decision-making.

Stage 2 migration begins to coalesce as households take account of the uncertainty of long-term mining prospects and plan by investing their savings in multi-locational, off-mining site housing mostly in nearby regional towns or the regional capital. They choose locations based on the household head's income standing, age, experience and current and future projected business investment interests. Stage 2 migration is often staggered with family members moving and taking up residence at different points in time, in an already built or in the process of being built residential house, given practical life-cycle considerations of individual family members. Stage 2 culminates when the head of household and all family members have ceased to live in the mining settlement and have taken up residence in a non-mining urban settlement. Capital movement generally precedes actual population out-migration, and therefore represents a blurred interim between direct and indirect urbanization, with Stage 2 indirect urbanization only being fully realized when miners and service providers relinquish their mine site residence. 


\section{Stage 1: Migration to mining sites and direct urbanization}

Artisanal miners' motivation to go to their first mining site is usually based on aspirations for livelihood improvement. ${ }^{26}$ By contrast, at their second site and onwards, they are primarily driven by the quest for mineral strikes and better mining opportunities. In this endeavour, they often end up mining increasingly further away from their original home areas. The story of John J., a 34-year-old miner, interviewed in Nyarugusu at the time of a gold rush in the neighbouring village of Nyaruyeye, is indicative of the mobility of many artisanal miners.

I was born in a village in Bariadi District in Shinyanga Region. My father was a gold buyer and often brought home cash from his business. This gave me the motivation to enter artisanal mining. In late 1997, when I was 20, I went to the Matabe gold rush in Kagera Region, where I earned good money. But as young men, most of our money was spent on entertainment, booze and women. In 2002, I got three million shillings and began to build a house close to Matabe in the district of Chato. 2005 was my best year so far. I was mining in Tulawaka, both outside and within the concession area of the Tulawaka Gold Mine owned by Barrick. We bribed the guards to 'look the other way' and stole gravel containing a lot of gold. So far, I have mined at eight different locations in four different regions. These days I live in the house I built in Chato and only mine for gold when there is a rush. ${ }^{27}$

John J. was interviewed in Nyarugusu during his first visit to the settlement. His immediate plan was to join a mining team at a high-yielding pit where they would welcome his experience. If he earned enough money, he planned to improve his house and do business.

Miners' and entrepreneurs' readiness to travel significant distances to mining sites and their limited sense of rootedness to their work sites when better opportunities present themselves elsewhere is illustrated by the UPIMA data. Only $17 \%$ of the interviewed household heads in our four artisanal mine sites were born within the settlement that they were residing in at the time of the survey: $29 \%$ were from within the district or a neighbouring district, whereas the majority (54\%) hailed from distant districts and regions throughout the country. Miners with several years of experience were the most mobile, typically having mined at multiple locations.

Artisanal miners' migration motives, evolving over their individual life cycles, are heavily influenced by the stage of the settlement's mineral wealth exploitation. Sixty-nine\% of the sampled migrant household heads arrived at the Ikuzi gold rush site intending to mine, alongside $14 \%$ who were attracted by business prospects, hoping to capitalize on the spike in the purchasing power associated with the gold rush. In Mwanangwa's diamond rush setting, 36\% of household heads were motivated by mining opportunities, while $11 \%$ sought business. Being a long-established village, $33 \%$ of respondents were native-born residents and another $8 \%$ had come looking for farming opportunities, 
an indicator of the village's agrarian origins. Despite Nyarugusu's maturity as a gold mining settlement since the 1980 s, it continued to attract an incoming population with $44 \%$ of households migrating explicitly to mine, $28 \%$ searching for employment more generally, and $17 \%$ coming for unspecified family reasons. In the other mature mining settlement of Maganzo, notably, $42 \%$ of respondents were born on-site, $17 \%$ came to look for employment, and $14 \%$ came explicitly to participate in mining. This latter percentage needs to be understood in the context of ubeshi (see Table 1). It is likely that the low percentage of people coming to Maganzo to mine reflects reticence about their illegal mining activities on the perimeter of the large-scale mine at Mwadui.

The physical transformation of a mining site from bush in a remote location to a mineral excavation site with temporary housing to a mature mining settlement with permanent housing able to economically sustain its population depends on the size of the mineral deposit, the nature of mineral tenure and the scale of mining equipment. Firstly, if artisanal miners secure mineral rights and near-tosurface deposits are plentiful, as seen in Nyarugusu, artisanal mine sites can evolve into permanent towns due to residents' willingness to invest their time and money in housing improvement. An alternative outcome arises when artisanal mining at the site wanes but residents' successful livelihood experimentation generates sectoral diversification towards agricultural, industrial and/or service sector activities and encourages residents' investment in permanent housing. In some cases, the first and second possibilities alternate with repeated mining strikes interspersed with mining lulls in which people must improvise with livelihood diversification.

Comparing our surveyed rush and mature mining sites, the rush sites were primarily characterized by makeshift housing, consisting of tarpaulins and locally available materials. In Ikuzi, $92 \%$ of the respondents used tarpaulins and it was rare for them to have mud walls (25\%), whereas the existing village at the diamond rush site at Mwanangwa precluded the need for tarpaulins: village residents rented out rooms to miners in their houses. Most miners (83\%) slept under thatched roofs with mud walls.

Even in rush settlements, surveyed respondents who stay longer on-site manage to ameliorate their housing conditions. In Ikuzi, respondents' house size expanded from 1.4 to 2.4 rooms on average within two months. Mwanangwa registered the least progression, from 3.3 to 3.6 rooms within a period of nearly 14 years, indicating that space and land entitlement for incoming miners was limited.

In the mature gold and diamond mining settlements, residential accommodation progressed over the passage of time. In Nyarugusu, respondents indicated that their number of rooms had increased from 2.3 to five rooms over seven years. In Maganzo, room increase was more constrained going up from 3.3 to 4.4 rooms over ten years. 
Surveyed household heads' views on the location of their home reflect a clear transition from rush to mature sites. Only 39\% in the Ikuzi gold rush site felt 'at home', as opposed to 64\% at the Mwanangwa diamond rush site located in an existing village where our interviewing took place past the peak of the rush. By contrast, the mature sites of Nyarugusu and Maganzo had $94 \%$ of their respondents - on average - identifying their current site as home. Accordingly, only $6 \%$ of Ikuzi's and $36 \%$ of Mwanangwa's respondents wanted to stay in situ during their retirement, while the same figures for Nyarugusu and Maganzo were $64 \%$ and $81 \%$ respectively.

\section{Between Stage 1 and 2: Housing capital accumulation and locational preferences}

Most artisanal miners and mine site resident respondents were keen to save and invest, but had insufficient earnings to do so. Only $40 \%$ of houses were making investments. The odds of investing were considerably higher for households in gold-mining sites (Table 2). Ikuzi gold rush respondents invested more over the preceding year than in any other settlement. Generally, gold settlement residents were able to make more and bigger investments than respondents in the diamond settlements, with one fifth of households in gold settlements achieving entry into the over-US\$1000 league of investors.

Table 2: Investment patterns by settlement during previous year

\begin{tabular}{lccc}
\hline Survey sites & $\begin{array}{l}\text { Average } \\
\text { number of } \\
\text { investments }\end{array}$ & $\begin{array}{l}\text { Respondents with } \\
\text { 1 or more } \\
\text { investments } \% \text { of } \\
\text { households) }\end{array}$ & $\begin{array}{l}\text { Respondents with } \\
\text { investments above } \\
\text { US\$1000 (\% of } \\
\text { households) }\end{array}$ \\
\hline Rush sites & 1.5 & 42 & 15 \\
\hline Gold-Ikuzi & 1.8 & 56 & 22 \\
Diamonds-Mwanangwa & 1.2 & 28 & 14 \\
\hline Mature sites & 0.9 & 39 & 8 \\
\hline Gold-Nyarugusu & 1.3 & 53 & 19 \\
Diamonds-Maganzo & 0.4 & 25 & 8 \\
\hline
\end{tabular}

Source: UPIMA Tanzania survey, May 2011-March 2012

People's main investment aims were focused on house construction, livestock, land purchases, and business.

Table 3: Most common household investments in each settlement (\% of households) 


\begin{tabular}{lcccc}
\hline Survey sites & House & Livestock & Business & Land \\
\hline \hline Rush sites & $\mathbf{1 2 . 5}$ & $\mathbf{1 3 . 9}$ & $\mathbf{1 . 4}$ & $\mathbf{1 . 4}$ \\
Gold-Ikuzi & 22.2 & 11.1 & & \\
Diamonds-Mwanangwa & 2.8 & 16.7 & 2.8 & 2.8 \\
Mature sites & $\mathbf{1 3 . 9}$ & $\mathbf{5 . 6}$ & $\mathbf{4 . 2}$ & $\mathbf{5 . 6}$ \\
Gold-Nyarugusu & 27.8 & 11.1 & & \\
Diamonds-Maganzo & & & 8.3 & 11.1 \\
& & &
\end{tabular}

Source: UPIMA Tanzania survey, May 2011-March 2012

While house construction and house improvement dominated investments, it cannot be assumed that such investments necessarily took place in the mining settlement. This was especially the case in gold rush Ikuzi, where none of the respondents originally came from the nearby settlement. Most of their savings were spent or invested in the surrounding towns of Kahama, Runzewe, Geita and Mwanza. One elderly Ikuzi artisanal miner who had successfully invested explained:

I have built a house in Geita Town with bricks and iron roofing and bought 60 acres of land and 18 cattle in my home region of Kagera, but in Ikuzi, I live in a small room with my second wife. ${ }^{28}$

People primarily tried to save some of their earnings with the intention of eventually leaving and investing elsewhere given the uncertainty of the site's future. The locations where household heads built their most valuable houses were a telling indicator of their level of mobility and the spatial trajectory of their lives. While Ikuzi residents built their main, most expensive house in towns (42\%), at the mine site (28\%) and in their home villages (17\%), people in the mature mining sites had a different pattern. In Nyarugusu and Maganzo, 86 and 83\% of respondents, respectively, resided in what they considered their main house.

Table 4: Location of owned house of highest value (\% of households)

\begin{tabular}{lcccccc}
\hline Survey sites & $\begin{array}{c}\text { Current } \\
\text { mine site }\end{array}$ & $\begin{array}{c}\text { Previous } \\
\text { mine site }\end{array}$ & Towns & $\begin{array}{c}\text { Home } \\
\text { village }\end{array}$ & $\begin{array}{c}\text { Other village } \\
\text { houses } \\
\text { owned }\end{array}$ \\
\hline Rush sites & $\mathbf{4 0 . 3}$ & $\mathbf{2 . 8}$ & $\mathbf{2 6 . 5}$ & $\mathbf{1 1 . 2}$ & $\mathbf{2 . 8}$ & $\mathbf{1 6 . 7}$ \\
\hline Gold-Ikuzi & 27.8 & 5.6 & 41.7 & 16.7 & 5.6 & 2.8 \\
\hline Diamonds- Mwanangwa & 52.8 & & 11.2 & 5.6 & $\mathbf{3 0 . 6}$ \\
\hline Mature sites & $\mathbf{8 4 . 7}$ & & $\mathbf{4 . 2}$ & $\mathbf{1 . 4}$ & $\mathbf{9 . 8}$ \\
\hline Gold-Nyarugusu & 86.1 & 8.4 & & 5.6 \\
Diamonds-Maganzo & 83.3 & & 2.8 & 13.9 \\
\hline
\end{tabular}




\begin{tabular}{lllllll}
\hline Average & 62.5 & 1.4 & 15.3 & 6.3 & 1.4 & 13.2 \\
\hline
\end{tabular}

Source: UPIMA Tanzania survey, May 2011-March 2012

Nonetheless, all our qualitative interviews with people in the four settlements indicate that residents want to invest the main share of their earnings outside the mining settlement in large urban areas, notably in Mwanza city and large regional towns like Geita, Shinyanga, and Kahama. At Nyarugusu secondary school, one student observed:

People in Nyarugusu who succeed in getting big money run with their money and invest in either Dar es Salaam, Mwanza or Geita. Nyarugusu is their place to find money, but not their place to invest it. They want to go to Mwanza because of the availability of good social services, business opportunities, and security; amenities that are not present in Nyarugusu. ${ }^{29}$

Furthermore, Nyarugusu residents remarked that miners accustomed to spending their surplus cash on luxury goods, alcohol and women, were increasingly prioritising house construction instead. Such housing and property investments were made in places of the miners' origin or major towns like Mwanza and Geita. ${ }^{30}$ As one septuagenarian observed: "Only a few build modern houses in Nyarugusu. Most people who get rich or earn good money in Nyarugusu choose to build in the bigger towns". ${ }^{31}$ Similarly, in Maganzo, most people's profits from diamond mining, and especially trading, are used mainly to build private houses for renting out in major towns like Dar es Salaam, Mwanza, Shinyanga, and Arusha. ${ }^{32}$

When respondents were asked whether they desired to live elsewhere if they had the opportunity, rush site residents (75\%) were keen to leave, particularly the gold miners (83\%), whereas mature mining site residents (53\%) were considerably more complacent evidencing a relatively small difference between the gold site (58\%) as opposed to the diamond site (64\%). The response to this question contrasts with their "perception of home" and "anticipated retirement destination". Such varied responses point to the importance of studying artisanal mine site residents with a multilocational perspective to fathom what people are actually doing as opposed to what they would like to do.

Table 5 reveals the lure to urban areas. Forty six \% of respondents across all sites favoured towns, followed by their current mine site, Dar es Salaam, and other villages as their preferred location.

Table 5: Preferred location if opportunity arises

\begin{tabular}{lccccc}
\hline Survey sites & $\begin{array}{c}\text { Current } \\
\text { mine site }\end{array}$ & $\begin{array}{c}\text { Other mine } \\
\text { site }\end{array}$ & $\begin{array}{c}\text { Dar es } \\
\text { Salaam }\end{array}$ & Towns & $\begin{array}{c}\text { Other } \\
\text { villages Other }\end{array}$ \\
\hline \hline Rush sites & $\mathbf{2 4 . 5}$ & $\mathbf{1 . 4}$ & $\mathbf{9 . 8}$ & $\mathbf{5 5 . 5}$ & $\mathbf{8 . 4}$
\end{tabular}




\begin{tabular}{|c|c|c|c|c|c|c|}
\hline Gold-Ikuzi & 16.6 & 2.8 & 16.7 & 52.7 & 11.1 & \\
\hline Diamonds-Mwanangwa & 33.3 & & 2.8 & 58.3 & 5.6 & \\
\hline Mature sites & 47.3 & & 8.4 & 36.1 & 7.0 & 1.4 \\
\hline Gold-Nyarugusu & 41.7 & & 11.1 & 44.5 & & 2.8 \\
\hline Diamonds-Maganzo & 52.8 & & 5.6 & 27.7 & 13.9 & \\
\hline Average & 36.1 & & 9 & 45.8 & 7.6 & 1.4 \\
\hline
\end{tabular}

Surprisingly, none of the respondents mentioned their home village as a preferred site, and only one person mentioned another mine site. While many artisanal miners originating from villages use their initial earnings on building or improving their own or their relatives' rural houses, as their careers as miners consolidate, they are increasingly attracted to economic opportunities in urban settings, notably Mwanza city, which exerts the greatest attraction.

\section{Stage 2: Indirect urbanization: From 'making a living' to 'living life' in Mwanza City}

This section centres on those artisanal miners who manage to save considerable income from mining and go on to seek profitable investment and safer and healthier lives in urban areas. Beyond its function as the administrative capital of Mwanza Region and Tanzania's second largest city with a population of over 700,000 people, Mwanza is an international gateway to the Great Lakes region. Since the British colonial period, it has been known as the country's centre for cotton and freshwater fish exports. However, over the last three decades, Mwanza's strategic location vis-à-vis the mineral richness of surrounding districts, has contributed to making the city a mecca for business-minded people.

The city covers an area of $436 \mathrm{~km}^{2}$ with ample space for building expansion. Mwanza has an urban centre of towering high-rise buildings of five to ten storeys, an industrial area by the lake, flanked by Capri Point, a neighbourhood of upscale housing overlooking the lake occupied by affluent business people, managers and expatriates working for western NGOs or large-scale mining companies and their sub-contractors. Nonetheless, much of the city's housing is ramshackle in appearance, often perched precariously on the city's many hillsides and in lower-lying neighbourhoods spread out in the city's outskirts.

Since the mass movement of artisanal miners began in the 1980s, the first cohort of artisanal miners has come of age. With their eyes set on easing away from labour-intensive pit mining, those who can afford to do so, gradually veer from mining sites towards district and regional towns and cities, with Mwanza being the most prominent destination. Between 2002 and 2012, Mwanza's 
intercensal growth rate superseded that of Dar es Salaam. Successful artisanal miners form a notable part of the population influx. Their housing and business investments in the city represent years of hard work, providing them with the financial means to achieve upward social mobility.

Our semi-structured interviews with the nine key miner-cum-entrepreneur informants in December 2012 provide examples of artisanal miners' life trajectories, which have catapulted them to establishing residences and businesses in Mwanza. Current and former artisanal miners were identified through snowball sampling. They ranged between 34 and 55 years of age, averaging 47 years of age. All interviewees had achieved variable success in their mining careers and had used their earnings from mining to construct houses made of bricks or building blocks and roofs of iron sheets or, in a few cases, more prestigious tiles. Perhaps significantly, all nine were ethnically Sukuma, the indigenous and demographically dominant tribe in the city and region. While nine interviews are too few to make large generalizations, their observations and housing investment histories are indicative of the life trajectories of successful artisanal miners.

Artisanal pit miners constitute an informal fraternity of men who share a history of taking calculated risks for the sake of finding mineral wealth. Many have started mining in their teens. Their work is exceptionally strenuous, such that men in their mid-40s are already thinking of ways of finding less physically taxing ways of earning their livelihood. Three were engaged in petty business, one rented out a ball mill for gold ore processing, one rented houses he had built as well as being engaged in artisanal gold mining and trade, including buying gold in the Democratic Republic of Congo and selling it in Dar es Salaam. Of the remaining four, all still had a strong foothold in artisanal mining through ownership of mining claims and leaching plants for the processing of gold. They were also involved in building hotels or guesthouses in Mwanza, large-scale commercial farming, and numerous other business activities.

Each of the interviewees had charted an economic journey of luck and calculated planning. Juma G., a 51-year-old artisanal miner explained:

In 1988, I earned Tsh 60,000, which was a lot of money back then. I went home with Tsh 45,000, bought 11 cattle and gave the rest to my parents. That gave me a lot of respect at home. But these days I feel like a Mwanza resident and I plan to retire here. When I visit my home village, I am treated like a guest. I have helped two of my brothers to build their houses in the village, but I have never considered building my own there. ${ }^{33}$

Eight out of the nine interviewees were born in rural areas and all were unequivocal in their limited attachment to their places of origin. Samweli M., a 55-year-old artisanal miner operating a successful business in Mwanza city, recounted: 
After I retired from the army as a sergeant in 1988, I started mining with my brother. The first day I earned Tsh 18,000 whereas I had been earning Tsh 6,000 a month in the army. I was immediately hooked on mining. Presently I am building a house in Mwanza. I have helped my brother improve our parents' house in our home village, but I do not intend to live there. I actually feel like an outsider when I visit home. I feel different from them. ${ }^{34}$

Fifty-four-year-old successful artisanal miner and businessman Yusuph M. explained that there were cultural constraints impinging on his economic investments.

I built a house in my home village in 1996, just a small house with two bedrooms and a living room made of bricks and iron roofing. It is not common in our culture to build a very nice house in your home village. It can create envy and sometimes bewitchment. ${ }^{35}$

Similarly, Leonard M., a retired 41-year-old artisanal miner expressed disdain of rural superstition:

I decided not to build a house in the village because of the threat of witchcraft, local women who would be chasing me, and the cultural rules that I would have had to follow. I distanced myself from the village because of its cultural norms. I was the oldest son when my father died and the traditions prescribed that I was then responsible for the livestock; something that did not attract me, as it involved long days of cattle rearing. ${ }^{36} 37$

Ahmed B., a 49-year-old artisanal miner who had mined on and off since 1985, narrated how he found a place to settle.

I avoided returning to build a house in my home village because of my relatives' expectation and demand for pocket money and support. If you are known to have money in a village, you get trouble with your peers and relatives, and with security. Villagers always want to borrow money and the bad ones want to steal from you. Instead, I decided to build in Mwanza. It was the logical place to move to. I had many friends in Mwanza and would always be able to rent out my house if I moved elsewhere or needed extra money. I carry on mining in various places but I plan to retire here, where many artisanal miners like myself have built houses. ${ }^{38}$

Some of the other interviewees deliberately choose not to live in an artisanal mine site as exemplified by Samweli M., who, despite owning two houses in artisanal mine settlements, had reservations about permanently residing there:

Although my wife and most of my children are currently living in Nyarugusu, I never saw Nyarugusu or Nyakagwe, where I also have a house, as places for settling down permanently. They are places for earning money. I want to live and retire in Mwanza. ${ }^{39}$ 
Leonard M., a 41-year-old ex-miner who started mining as a teenager in 1986, experienced a big gold find in 1997. He left the site and mining activities the same day to circumvent fellow miners likely to expect loans and gifts because of his good luck. Norms of reciprocity within the local mining economy prevail. One is expected to support others in good times and receive support when times are hard.

In Kalenge, I was really lucky finding a stone in the tunnel wall that consisted almost entirely of gold. After processing, it weighed nearly half a kilo worth 12 million shillings; a small fortune back then. I left the site immediately without saying goodbye, settled in Mwanza, and never returned to mining. ${ }^{40}$

At informal mining settlements, residents always live under the threat of eviction. John. J., a 49year-old artisanal miner, who had mined since 1983 explained: 'I did not invest in a proper house in Mgusu. No one did and there was always the risk of eviction; Mgusu being an informal gold mining settlement'. ${ }^{41}$

Leonard M., emphasizing the importance of distancing himself from his former mining life, recalled:

I once spent seven million shillings in a few weeks on a drinking spree in Dodoma. We were accustomed to taking taxis for hundreds of kilometres in connection with celebrating gold rush success. And in drinking sprees, we commonly stacked crates of beer higher than people's heads in preparation for drinking it all. I chose Mwanza to build a house and live, as I wanted to remove myself from the world of mining and all its temptations. In Mwanza, you can drink two to three beers and call it a day, but in the mining fields, there is always another guy ready to buy another round. Also, I wanted to stay as far away from my former co-workers, who were not happy with my sudden departure and wealth; they felt cheated. ${ }^{42}$

Many of the interviewees in Mwanza stressed that they and other miners these days prefer using their earnings on household investments as opposed to their previous practice of spending a large portion of their earnings on entertainment. Leonard M. explained how miners' consumer objectives have changed:

Formerly when a miner got money, he wanted to build respect in the mine site, flash his money around and be a big man - at least for a few days. But nowadays people take their money home or to town. Alcohol consumption and partying is not as widespread as it used to be. The craziness has declined and people use their money more wisely, and are interested in building houses. ${ }^{43}$

Kambi A. agreed: 
It seems like artisanal miners invest their earnings more than previously; they buy means of transport, start small businesses and build houses. People learn from others and begin to use their money more wisely. ${ }^{44}$

Yusuph M. further elaborated:

Formerly when artisanal miners got money, they invested it at home. Amongst the Sukuma people, money was often spent on livestock. These days, people are more inclined to build at the mine site if it develops, or in towns offering adequate physical and social infrastructure. If people earn around five million shillings, they are inclined to build a house at home or at the mine site depending on the development of the mine site. These days people choose large towns or industrial mine sites where the settlement's long term resilience seems obvious, for example Kahama and Geita. If they earn around Tsh 40 million, they are likely to start a business or build a modern house. Artisanal miners typically invest in guesthouses or bars. If a miner gets over Tsh 100 million, he moves to a larger town or city and tries to change his life, due to the attractions of city life and because he knows people will be asking him for money continuously if he stays in the artisanal mine site. ${ }^{45}$

The interviewees chose to build in Mwanza for a number of reasons, including improved social and physical infrastructure, entertainment opportunities, the possibility of achieving good business profits, the opportunity to distance themselves from their mining past including former mining peers and the attraction of staying in an urban setting where many of them, being from the Sukuma tribe, felt culturally more at home than in other large cities in Tanzania like Dar es Salaam and Arusha.

Juma G. was very conscious about his choice of settling down in Mwanza.

When I was living in Nyarugusu, I asked myself why we miners always move around. I decided to find an ideal place to locate my family. It had to be a suitable place where they could live while I was pursuing mining opportunities around the regions. I settled them in Mwanza, where the children could get good education without being attracted by the temptations of gold mining before completing their education. If they followed me around to various mine sites, there would be a high risk of them dropping out of school. Now, instead, all my children are schooling, one in college, one in Form 4, two in Form 3 , and the rest in primary school. ${ }^{46}$

Yusuph M. had seriously considered relocating to Dar es Salaam but decided against it:

Dar es Salaam is too far away, too hot and too expensive. Mwanza is my home region, where I have many friends and relatives close by to help me supervise my businesses. It is also the home of the Sukuma, which makes me feel at home culturally. ${ }^{47}$

Kambi A., a 42-year-old artisanal miner born in Kigoma, also chose Mwanza over Dar es Salaam: 
My parents died when I was young and although I still have relatives at home, I do not feel an urge to build there. In Mwanza, I have many friends and relatives and I like the place. Also, if I end up living elsewhere, I can always rent out the house, which is what many people do. Dar es Salaam was never an option. It is far away and I have only visited the city a few times. ${ }^{48}$

Thus, the urban primacy of Dar es Salaam does not necessarily prompt people to relocate there. Its location - more than 1,000 kilometres from Lake Victoria - and the cultural 'foreignness' of the commercial capital make Dar es Salaam a less attractive place for successful artisanal miners than more proximate and culturally familiar Mwanza.

\section{Conclusion}

Our concept of urbanization relates to multi-locational investment of miners and other service sector migrants striving to accumulate wealth in situ in artisanal mining settlements. If successful, they are likely to pursue diversified investments in urban areas. Such indirect urbanization emanates from mining settlements, starting with outward-bound capital investment in housing and business in larger, more populous urban areas eventually followed by migration.

Decisions about where to make housing investments involve strategic decision-making contingent on artisanal miners' level of mining success and life cycle needs. Their considerations encompass children's education, family safety and security, management of diversified multi-locational businesses and comfort and care in retirement. Residential choices in first stage migration and direct urbanization are influenced by work and profit-considerations whereas second stage migration and indirect urbanization involve a welter of aims connected to improved living standards and quality of life.

Miners' off-mining site investments into housing are at the heart of their strategies for economic advancement. Beyond artisanal miners' strategic locational decision-making for the furtherance of their careers, their residential mobility has had a profound impact on Tanzanian urbanization over the past three decades. Artisanal miners' migration to mining sites markedly boosted small town growth during the 1990s in the regions south of Lake Victoria. ${ }^{49}$ The process of "indirect urbanization", as defined in this article, has contributed significantly to the growth of secondary towns, intermediate cities and large cities like Mwanza.

Artisanal mining is a phenomenon that has received scant attention from policy makers in Tanzania and yet its occupational and locational patterns have done much to realign the demography of the nation. Artisanal miners' population movement and multi-locational housing investments have 
fuelled direct and indirect urbanization. From artisanal mining's early clandestine inception in the rural areas, through artisanal miners' mass migration to lucrative mining sites that transformed rural locations into small towns and created far-flung population-densifying urbanization in the Lake Victoria Gold Fields. Some of that small town population base has proceeded outwards, surfacing as indirect urbanization by successful miners-cum-entrepreneurs in large regional towns and intermediate cities, and has boosted Mwanza's population and large city status in Tanzania's urban hierarchy. Part of this development has been spurred by a shift in the expenditure patterns of artisanal miners from conspicuous consumption to a prioritising of housing construction, as mentioned by many informants. The legalization of artisanal mining, increasing availability of modern building materials, and appreciation of the 'non-renewable' nature of minerals has bolstered this tendency.

Awareness of the multi-locational strategic decision-making of artisanal miners is vital to understanding the relationship between artisanal mining and urban growth, and the interacting dynamics of direct and indirect urbanization. Theoretically, our use of the term indirect urbanization derives from a developmental context in which artisanal miners, who have saved and invested earnings from mining, often shun permanent settlement in either the mine site or their home areas because of the social pressure on them to share their wealth and return to rural norms and livelihoods. Thus, artisanal miners and other mining residents are self-selecting for an urban cosmopolitan life where they can extend their multi-locational housing and diversified business investments. This group of minerscum-entrepreneurs have contributed demographically and economically to the nation's overall rate of urban growth by moving from small towns to large towns and cities.

\section{Acknowledgements}

The authors would like to thank all the artisanal miners, residents of mine sites and key informants who made this study possible. Thanks also to Christina Nsekela and Catherine Sarunday for commenting on an earlier drafts of the paper. Research for this article was made possible due to the University of Glasgow's Urbanization and Poverty in Mining Africa (UPIMA) project funded by the UK Department for International Development (DfID) and the Economic Research Council (ESRC RES-167-25-0488).

\section{Bibliography}

Banchirigah, S.M. (2008) 'Challenges with eradicating illegal mining in Ghana: A perspective from the grassroots'. Resources Policy 33(1): 29-38. 
Bryceson, D.F. (1999) 'African rural labour, income diversification and livelihood approaches: A long-term development perspective'. Review of African Political Economy, no. 80. 171-89.

Bryceson, D.F. \& J.B. Jønsson, (2010) 'Gold digging careers in rural East Africa: Small-scale miners' livelihood choices'. World Development 38(3): 379-392.

Bryceson, D.F. (2011) 'Birth of a market town in Tanzania: Towards narrative studies of urban Africa'. Journal of Eastern African Studies 48(3): 353-82.

Bryceson, D.F. \& D. MacKinnon (2012) 'Eureka and beyond: Mining's impact on African urbanisation'. Journal of Contemporary African Studies 30(4): 513-37.

Bryceson, D.F., J.B. Jønsson, C. Kinabo \& M. Shand (2012) 'Unearthing treasure and trouble: Mining as an impetus to urbanisation in Tanzania'. Journal of Contemporary African Studies 30(4): 631-649.

Bryceson, D.F., E. Fisher, J.B. Jønsson \& R. Mwaipopo (eds) (2014) Mining and Social

Transformation in Africa: Mineralizing and Democratizing Trends in Artisanal Production. London: Routledge.

Carstens, J. \& G. Hilson (2009) 'Mining and grievance in rural Tanzania'. International Development Planning Review 31(3): 301-26.

Chachage, C.S.L. (1995) 'The meek shall inherit the earth but not the mining rights: Mining and accumulation in Tanzania'. in Gibbon, P. (ed) Liberalised Development in Tanzania. Uppsala: Nordic Africa Institute.

Deshingkar, P. \& J. Farrington (eds) (2009) Circular Migration and Multilocational Strategies in Rural India. New Delhi: Oxford University Press India.

Emel, J. \& M.T. Huber (2008) 'A risky business: Mining, rent and the neoliberalization of "risk"'. Geoforum 39(3): 1393-1407.

Fisher, E., R. Mwaipopo, W. Mutagwaba, D. Nyange \& G. Yaron (2009) 'The ladder that sends us to wealth: Artisanal mining and poverty reduction in Tanzania', Resources Policy 34(1): 1-7.

Geenen, S. (2014) 'Qui cherche, trouve’ The Political Economy of Access to Gold Mining and Trade in South Kivu, DRC. Ph.D. thesis. University of Antwerp.

Gershman, B. (2016) 'Witchcraft beliefs and the erosion of social capital: Evidence from Sub-Saharan Africa and beyond'. Journal of Development Economics 120(2016): 182-208. 
Ghirotti, M. (1992) 'A simple method of scoring housing conditions as an income proxy in Ethiopia'. RRA Notes 15:43-47.

Jarmila, H. (2006) 'Evaluation of urbanization conditions and the creation of development visions of The Slovak Republic'. in Kvarda, W. (ed) Responsible Use of Soil and Land and Regional Development. Conference and Research Programme of the Academia Danubiana. 19th March-2nd of April 2006. Issue 3. Slovak University of Technology, Faculty of Civil Engineering, Bratislava.

Jønsson, J.B. \& D.F. Bryceson (2009) 'Rushing for gold: Mobility and small-scale mining in East Africa'. Development and Change 40(2): 249-279.

Kitula, A.G.N. (2006) 'The environmental and socio-economic impacts of mining on local livelihoods in Tanzania: A case study of Geita District'. Journal of Cleaner Production 14(3-4): 405-414.

Kulindwa, K., O. Mashindano, F. Shechambo, H. Sosovele (2003) Mining for Sustainable Development in Tanzania. Dar es Salaam: Dar es Salaam University Press.

Lange, S. (2011) 'Gold and governance: Legal Injustices and lost opportunities in Tanzania'. African Affairs 110(439): 233-252.

Maranz, D. E. (2003) 'African friends and money matters'. SIL International DigitalResources.

Ouředníček, M. 2008. 'Urban mobility'. Department of Social Geography and Regional Development, Urban and Regional Laboratory - URRlab, Charles University in Prague, Faculty of Science, Czech Republic. http://www.aughty.org/pdf/urban_mobility.pdf

Roe, A.R. \& M. Essex (2009) Mining in Tanzania - What Future can we expect? International Council on Mining \& Metals (ICMM) Workshop paper. London: ICMM.

Schmidt-Kallert, E. (2009) 'A new paradigm of urban transition: Tracing the livelihood strategies of multi-locational households'. Amenity Migration 3: 319-36.

Seto, K.C., B. Güneralpa \& L.R. Hutyra (2012) 'Global forecasts of urban expansion to 2030 and direct impacts on biodiversity and carbon pools'. Proceedings of the National Academy of Sciences, 109 (40): 16083-16088.

Start, D. \& C. Johnson (2004) 'Livelihood options? The political economy of access, opportunity and diversification'. Working Paper 233, Overseas Development Institute, London.

Tanzania, United Republic of (2011) Draft final report on baseline survey on artisanal and small-scale mining (ASM) activities and preparation of an ASM database, Sustainable Management of Mineral 
Resources Project (SMMRP), World Bank. Report prepared by MTL Consulting, Tan Discovery

Mineral Consulting, and PaulSam Geo - Engineering.

Tanzania, United Republic of (2008) Bomani report of the Presidential Mining Review Committee to advise the government on oversight of the mining sector, vol. 2, Dar es Salaam: translated by Paperworks Associates Tanzania on behalf of The Policy Forum. http://coet.udsm.ac.tz/biofuel\%20documents/7.\%20Bomani\%20Report\%20-\%20English.doc (accessed 17 September 2012).

Tanzania, National Bureau of Statistics, 2002 Tanzania Population and Housing Results. Dar es Salaam.

Tanzania, Ministry of Energy and Minerals (2010) The Mining Act 2010. Dar es Salaam: Government Printer.

Werthmann, K. (2010): 'Following the hills': Gold mining camps as heterotopias. Translocality'. in Freitag, U. \& A. von Oppen (eds.) The Study of Globalising Processes from a Southern Perspective. Leiden: Brill.

\footnotetext{
${ }^{1}$ Jønsson and Bryceson, "Rushing for gold"; Fisher et al, "The ladder that sends us to wealth".

${ }^{2}$ Bryceson and Jønsson, "Gold digging careers in rural East Africa".

${ }^{3}$ Chachage, "The meek shall inherit the earth but not the mining rights"; Emel and Huber, "A risky business"; Kulindwa et al, "Mining for Sustainable Development in Tanzania"; Roe and Essex, "Mining in Tanzania".

${ }^{4}$ Carstens and Hilson, "Mining and grievance in rural Tanzania"; Lange, "Gold and governance".

${ }^{5}$ Fisher et al, "The ladder that sends us to wealth"; Kitula, "The environmental and socio-economic impacts of mining on local livelihoods in Tanzania"; Bryceson et al, "Mining and Social Transformation in Africa".

${ }^{6}$ Banchirigah, "Challenges with eradicating illegal mining in Ghana"; Fisher et al, "The ladder that sends us to wealth"; Geenen; "Qui cherche, trouve"; Werthmann, "Following the hills".

${ }^{7}$ Bryceson and MacKinnon, "Eureka and beyond".

${ }^{8}$ Bryceson et al, "Unearthing treasure and trouble".

${ }^{9}$ Bomani Report, "Bomani report of the Presidential Mining Review Committee to advise the government on oversight of the mining sector".

${ }^{10}$ Chachage, "The meek shall inherit the earth but not the mining rights".

${ }^{11}$ Bryceson, "African rural labour, income diversification and livelihood approaches".

${ }^{12}$ Lange, "Gold and governance".

${ }^{13}$ Tanzania, United Republic of, "Draft final report on baseline survey on artisanal and small-scale mining (ASM) activities and preparation of an ASM database".

${ }^{14}$ Tanzania, Ministry of Energy and Minerals, "The Mining Act".

${ }^{15}$ Bryceson, "Birth of a market town in Tanzania".

${ }^{16}$ Jønsson and Bryceson, "Rushing for gold".

${ }^{17}$ Ghirotti, "A simple method of scoring housing conditions as an income proxy in Ethiopia".

${ }^{18}$ Werthmann, "Following the hills", 112.

${ }^{19}$ Bryceson and Jønsson, "Gold digging careers in rural East Africa"; Bryceson et al, "Unearthing treasure and trouble".

${ }^{20}$ Ouředníček, "Urban mobility".
} 
${ }^{21}$ Seto, "Global forecasts of urban expansion to 2030 and direct impacts on biodiversity and carbon pools".

${ }^{22}$ Jarmila, "Evaluation of urbanization conditions and the creation of development visions of The Slovak

Republic".

${ }^{23}$ Deshingkar and Farrington, "Circular Migration and Multilocational Strategies in Rural India".

${ }^{24}$ Start and Johnson, "Livelihood options?".

${ }^{25}$ Schmidt-Kallert, "A new paradigm of urban transition".

${ }^{26}$ Jønsson and Bryceson, "Rushing for gold".

${ }^{27}$ John J., 4 September 2011, Nyarugusu Village.

${ }^{28}$ Zaidi M. (60-year-old), 8 July 2011, Ikuzi Village.

${ }^{29}$ Focus group discussion, 3 October 2011, Nyarugusu Village.

${ }^{30}$ Richard K. (40-year-old), 4 September 2011, Nyarugusu Village.

${ }^{31}$ Kapella M. (72-year-old), 6 September 2011, Nyarugusu Village.

32 Harune M. (48-year-old), 21 September 2011, Maganzo Village; Justin N. (26-year-old), 19 September 2011, Maganzo Village; and Hendry P. (20-year-old), 20 September 2011, Maganzo Village.

${ }^{33}$ Juma G. (51-year-old), 22 December 2012, Mwanza City.

${ }^{34}$ Samuel M. (55-year-old), 21 December 2012, Mwanza City.

${ }^{35}$ Yusuph, M. (54-year-old), 18 December 2012, Mwanza City.

${ }^{36}$ Leonard M. (41-year-old), 20 December 2012, Mwanza City.

${ }^{37}$ Concealing one's financial status due to social pressure to share wealth, witchcraft threats, and witchcraft accusations is a well-known phenomenon in Sub-Saharan Africa and elsewhere reported by several observers (e.g. Gershman 2016; Maranz 2003). However, in the case of migrant artisanal miners, they are often in possession of considerable more wealth than their relatives in the rural areas, making the challenge of returning to one's home area more pronounced, prompting many to consider building their primary dwelling elsewhere.

${ }^{38}$ Ahmed B. (49-year-old), 20 December 2012, Mwanza City.

${ }^{39}$ Samweli M, (55-year-old), 21 December 2012, Mwanza City.

${ }^{40}$ Leonard M. (41-year-old), 21 December 2012, Mwanza City.

${ }^{41}$ John J. (49-year-old), 18 December 2012, Mwanza City.

${ }^{42}$ Leonard M. (41-year-old), 21 December 2012, Mwanza City.

${ }^{43}$ Leonard M. (41-year-old), 20 December 2012, Mwanza City.

${ }^{44}$ Kambi A. (42-year-old), 20 December 2012, Mwanza City.

${ }^{45}$ Yusuph, M. (54-year-old), 18 December 2012, Mwanza City.

${ }^{46}$ Juma G. (51-year-old), 22 December 2012, Mwanza City.

${ }^{47}$ Yusuph, M. (54-year-old), 18 December 2012, Mwanza City.

${ }^{48}$ Kambi A. (42-year-old), 20 December 2012, Mwanza City.

${ }^{49}$ Bryceson et al, "Unearthing treasure and trouble". 
Figure 1: Map of study sites

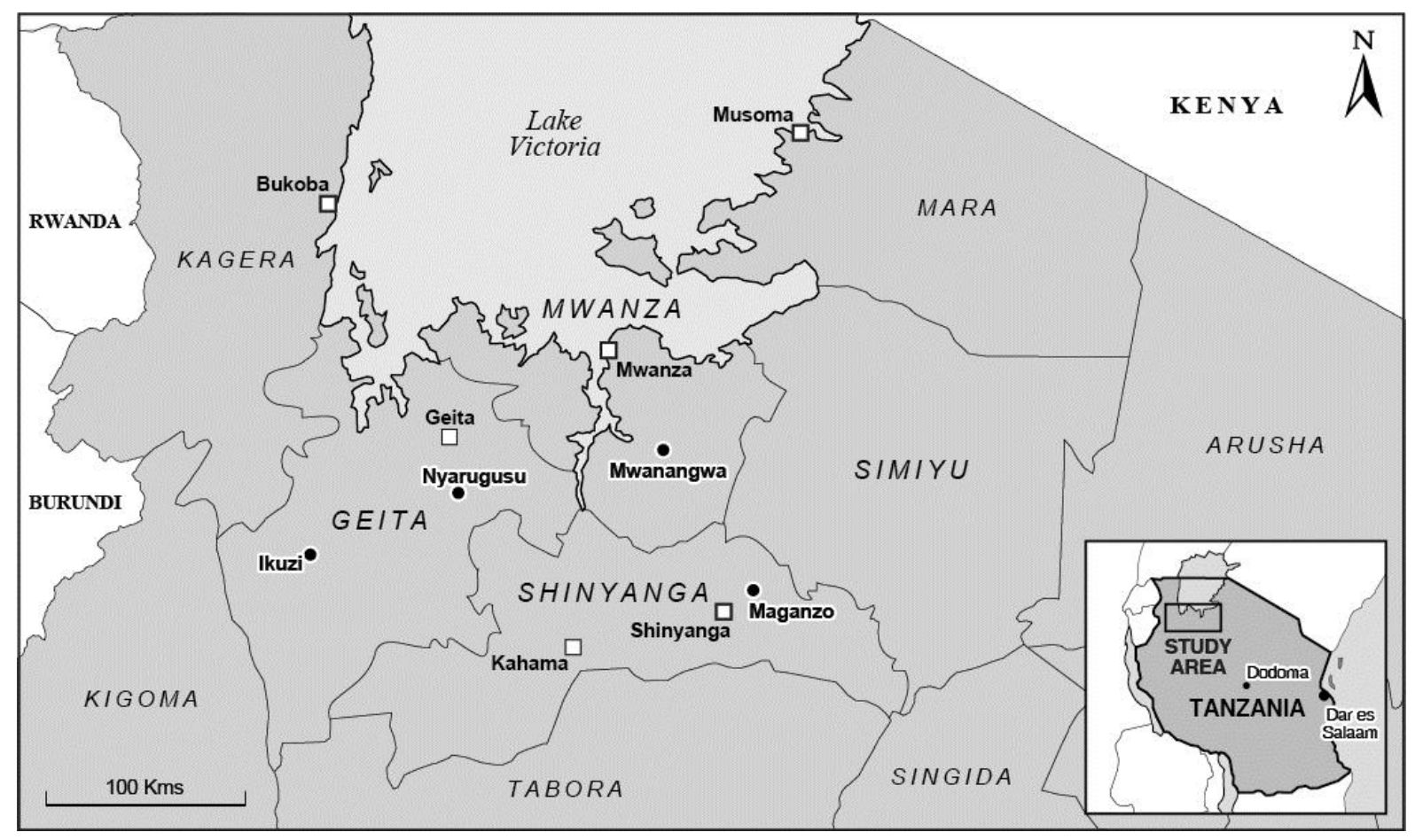

Source: M. Shand, 2016. 